\title{
THE DIURETIC EFFECTS OF LARGE DOSES OF ACETAZOLAMIDE AND AN ANALOG LACKING CARBONIC ANHYDRASE INHIBITING ACTIVITY *
}

\author{
By ARNOLD S. RELMAN, RICHARD PORTER, $\dagger$ JAMES F. TOBIAS $\ddagger$ AND \\ WILLIAM B. SCHWARTZ § \\ (From the Departments of Medicine, Boston University School of Medicine and Tufts Uni- \\ versity School of Medicine, and the Evans Memorial, Massachusetts Memorial \\ Hospitals, and the Pratt Clinic-New England Center Hospital, \\ Boston, Mass.)
}

(Submitted for publication April 18, 1960; accepted May 19, 1960)

According to current concepts, acidification of the urine in the distal tubule and final removal of bicarbonate from the glomerular filtrate occur by a process of ion exchange in which hydrogen ions within tubular cells are exchanged for sodium in the filtrate (1). It is thought that carbonic anhydrase catalyzes an essential reaction which either directly supplies hydrogen ions to the exchange site or removes the base generated by the secretion of hydrogen ions. In support of this hypothesis is the fact that unsubstituted sulfonamides which inhibit carbonic anhydrase prevent acidification of the urine and produce a diuresis of sodium and bicarbonate. Using sulfanilamide, Pitts and Alexander found that approximately 20 per cent of the filtered bicarbonate could be diverted into the urine (2), and suggested that the reabsorption of bicarbonate in the distal tubule was dependent on carbonic anhydrase activity.

Subsequently, however, it was pointed out by Berliner (3) and by Schwartz, Danzig and Relman (4) that acetazolamide, a more potent sulfonamide inhibitor of carbonic anhydrase, is capable of producing much greater effects on bicarbonate reabsorption. A dose of 20 to $30 \mathrm{mg}$ per $\mathrm{kg}$ of acetazolamide resulted in the loss of up to 50 per cent of the filtered bicarbonate, thus suggesting that a

* Supported in part by Public Health Service Grants A-330 and H-759 from the National Heart Institute, Bethesda, Md., and by a grant from the American Heart Association. Presented in part before the 76th annual meeting of the American Physiological Society, April, 1956.

$\dagger$ This work was done during the tenure of a Research Fellowship, American Heart Association.

$\ddagger$ This work was done during the tenure of a Charlton Research Fellowship in Medicine.

§ Established Investigator, American Heart Association. sodium-hydrogen exchange catalyzed by carbonic anhydrase might be responsible for the reabsorption of bicarbonate in the proximal as well as distal tubules $(3,4)$. With intravenous doses of 500 $\mathrm{mg}$ per $\mathrm{kg}$, even greater effects have been observed, with more than 75 per cent of the filtered bicarbonate appearing in the urine for a brief period after injection (5). Simultaneously, there was an enormous but transient diuresis, in which more than half of the filtered sodium and water was excreted.

These experiments were at first interpreted (4) as showing that the mechanism by which most, if not all, sodium reabsorption is accomplished involves the carbonic anhydrase-dependent hydrogen exchange described above. However, a more recent examination of this problem, using an $\mathrm{N}^{2}$ methyl analog (CL 8490) of acetazolamide which has little or no enzyme-inhibiting activity, indicates that this drug also is a potent diuretic when given in comparably large doses (5). The purpose of the present report is to present in detail the experiments with high doses of acetazolamide as well as to report comparative data with the analog. The results are compatible with the view that a significant part of the diuretic action of large doses of acetazolamide resides in an additional property of the drug not related to carbonic anhydrase inhibition. It is probable, however, that further inhibition of enzyme also plays a role.

\section{METHODS AND MATERIALS}

Anesthetized dogs were used in all experiments. For the most part sodium pentobarbital was employed, but in some experiments morphine was administered. In some experiments the animals were curarized and artificially ventilated with 100 per cent oxygen using an intermittent 
positive pressure device (Mine Safety Pneophore) and in other experiments the animals were allowed to breathe room air spontaneously. In most experiments arterial $\mathrm{PCO}_{2}$ ranged between 30 and $50 \mathrm{~mm} \mathrm{Hg}$, but in a few it was between 50 and $60 \mathrm{~mm} \mathrm{Hg}$. Continuous intravenous infusions of normal saline or saline and sodium bicarbonate were administered at rates necessary to maintain high urine flows and steady blood bicarbonate levels. Blood samples were collected from a catheter in the femoral artery, and infusions and all injections of drugs were made through a catheter in the femoral vein. The clearance of inulin or exogenous creatinine was used as a measure of glomerular filtration rate. Urine was collected under neutral mineral oil through an inlying bladder catheter. Inulin, $\mathrm{pH}$, creatinine, sodium, potassium, $\mathrm{CO}_{2}$ content and chloride were measured in blood and urine by standard methods, and $\mathrm{PCO}_{2}$ and bicarbonate were calculated from the Henderson-Hasselbalch equation. A Donnan factor of 1.05 was used in the calculation of the filtered load of bicarbonate.

The usual experimental plan was as follows. After stable blood levels and urine flow were established, two or more 10-minute control periods were obtained. The desired dose of sulfonamide was then injected intravenously over a period of 2 to 3 minutes. The dosage levels of acetazolamide were 10 and $500 \mathrm{mg}$ per $\mathrm{kg}$, and equimolar quantities of the analog (CL 8490) were employed (10.6 and $536 \mathrm{mg}$ per $\mathrm{kg}$ ). Drugs were administered in volumes of 10 to $90 \mathrm{ml}$. The free compounds were put into solution by the addition of 1.8 mmoles sodium hydroxide per mmole of drug to make a final $\mathrm{pH}$ of approximately 8.5 to 9.0 . In control experiments, sodium bicarbonate or sodium hydroxide was administered in amounts roughly equivalent to the alkali released into the blood by the larger doses of sulfonamide. Three minutes after the completion of each injection a blood sample was drawn, the bladder was emptied, the urine discarded and urine collections were begun anew. Because of the evanescent nature of the diuresis following the large doses, postinjection clearance periods were usually only 6 minutes in length.
The two sulfonamide compounds employed were: acetazolamide (Diamox, 5-acetamido-1,3,4-thiadiazole-2sulfonamide), and CL 8490 (N2-methyl-5-acetamido-1,3,4thiadiazole-2-sulfonamide. $)^{1}$ The latter substance has a titration curve which closely resembles that of acetazolamide. (Acetazolamide $\mathrm{pKa}^{\prime}{ }_{1}$ 7.4; $\mathrm{pKa}_{2}^{\prime}$ 9.1; CL 8490 $\left.\mathrm{pKa}^{\prime}{ }_{1} 7.7 ; \mathrm{pKa}_{2}{ }_{2} 10.0\right)$. However, CL 8490 does not demonstrate significant carbonic anhydrase inhibitory activity either in vitro or in vivo (6). In several experiments blood and urine samples obtained just before and after injection of the sulfonamide were assayed by Dr. Thomas Maren for their carbonic anhydrase inhibitory activity by the enzymatic method $(6,7)$.

\section{RESULTS}

\section{Comparative effects of equimolar small doses} of CL 8490 (10.6 $\mathrm{mg}$ per $\mathrm{kg}$ ) and accta olamide $(10 \mathrm{mg}$ per $\mathrm{kg}$ ). In five experiments $10.6 \mathrm{mg}$ per $\mathrm{kg}$ of CL 8490 was directly compared with $10 \mathrm{mg}$ per $\mathrm{kg}$ of acetazolamide. In all but one instance CL 8490 was injected first, followed in 1.5 to 2 hours by acetazolamide. In addition, CL 8490 was given alone on one occasion, and acetazolamide alone on two occasions. Table I summarizes the data from a typical experiment in which both drugs were given. Injection of CL 8490 produced little or no change in the renal excretion of water and electrolytes, and blood and urine contained no measurable carbonic anhydrase inhibiting activity. Subsequent injection of acetazolamide, on the other hand, was followed by a sharp rise in bicarbonate excretion and a reduction of approximately 40 per cent in the reabsorption of this ion. There was no

1 This analog, synthesized by the American Cyanamid Company, was made available through the kindness of Dr. Thomas H. Maren of the Research Division.

TABLE I

Comparative effects of equimolar small doses of CL $8490(10.6 \mathrm{mg} / \mathrm{kg})$ and acetazolamide $(10 \mathrm{mg} / \mathrm{kg})^{*}$

\begin{tabular}{|c|c|c|c|c|c|c|c|c|c|c|c|c|}
\hline \multirow{2}{*}{$\begin{array}{c}\text { Total } \\
\text { elapsed } \\
\text { time }\end{array}$} & \multicolumn{4}{|c|}{ Plasma } & \multirow[b]{2}{*}{ GFR } & \multicolumn{6}{|c|}{ Urine } & \multirow{2}{*}{$\begin{array}{l}\mathrm{HCO}_{3} \\
\text { reab- } \\
\text { sorbed }\end{array}$} \\
\hline & $\mathrm{pH}$ & $\mathrm{PcO}_{2}$ & $\mathrm{HCO}_{3}$ & $\begin{array}{c}\text { CAI } \\
\text { activity† }\end{array}$ & & Flow & $\mathrm{Na}$ & $\mathrm{K}$ & $\mathrm{Cl}$ & $\mathrm{HCO}_{3}$ & $\begin{array}{c}\text { CAI } \\
\text { activity }\end{array}$ & \\
\hline $\min$ & & $\stackrel{m m}{H g}$ & $m E q / L$ & $\mu g / m l$ & $m l / \min$ & $m l / m i n$ & \multicolumn{4}{|c|}{$\mu E q / \min$} & $\mu g / m i n$ & $\begin{array}{l}m E q / 100 \\
m l G F R\end{array}$ \\
\hline $\begin{array}{l}60-70 \\
70-80 \\
80-90 \\
90-92\end{array}$ & $\begin{array}{c}7.32 \\
7.32 \\
7.31 \\
\text { CL 8490, } 10.6\end{array}$ & $\begin{array}{c}38 \\
39 \\
41 \\
\mathrm{mg} / \mathrm{kg} \mathrm{i}\end{array}$ & $\begin{array}{r}20.0 \\
20.2 \\
20.3 \\
\text { v. }\end{array}$ & & $\begin{array}{l}70 \\
70 \\
72\end{array}$ & $\begin{array}{l}5.1 \\
5.1 \\
4.7\end{array}$ & $\begin{array}{l}955 \\
992 \\
949\end{array}$ & $\begin{array}{l}52 \\
49 \\
47\end{array}$ & $\begin{array}{l}975 \\
995 \\
951\end{array}$ & $\begin{array}{l}26 \\
27 \\
27\end{array}$ & & $\begin{array}{l}1.96 \\
1.98 \\
1.99\end{array}$ \\
\hline $\begin{array}{r}95-105 \\
105-115 \\
115-190\end{array}$ & $\begin{array}{c}7.31 \\
7.32 \\
\text { Discard }\end{array}$ & $\begin{array}{l}42 \\
40\end{array}$ & $\begin{array}{l}21.6 \\
21.3\end{array}$ & $\begin{array}{l}\mathbf{0} \\
\mathbf{0}\end{array}$ & $\begin{array}{l}70 \\
75\end{array}$ & $\begin{array}{l}4.5 \\
4.6\end{array}$ & $\begin{array}{l}932 \\
984\end{array}$ & $\begin{array}{l}41 \\
44\end{array}$ & $\begin{array}{l}926 \\
960\end{array}$ & $\begin{array}{l}37 \\
56\end{array}$ & $\begin{array}{l}\mathbf{0} \\
\mathbf{0}\end{array}$ & $\begin{array}{l}2.11 \\
2.06\end{array}$ \\
\hline $\begin{array}{l}190-200 \\
200-210 \\
210-212\end{array}$ & $\begin{array}{c}7.31 \\
7.33 \\
\text { Acetazolamide }\end{array}$ & $\begin{array}{c}40 \\
39 \\
10 \mathrm{mg}\end{array}$ & $\begin{array}{r}20.8 \\
21.1 \\
\mathrm{~kg} \text { i.v. }\end{array}$ & 0 & $\begin{array}{l}70 \\
76\end{array}$ & $\begin{array}{l}5.1 \\
4.9\end{array}$ & $\begin{array}{l}991 \\
969\end{array}$ & $\begin{array}{l}56 \\
55\end{array}$ & $\begin{array}{l}982 \\
957\end{array}$ & $\begin{array}{l}52 \\
51\end{array}$ & 0 & $\begin{array}{l}2.01 \\
2.04\end{array}$ \\
\hline $\begin{array}{l}215-225 \\
225-235\end{array}$ & $\begin{array}{c}7.35 \\
7.35\end{array}$ & $\begin{array}{l}37 \\
34\end{array}$ & $\begin{array}{r}20.2 \\
19.2\end{array}$ & $\begin{array}{l}25 \\
12\end{array}$ & $\begin{array}{l}56 \\
62\end{array}$ & $\begin{array}{l}7.7 \\
6.7\end{array}$ & $\begin{array}{l}1,350 \\
1,200\end{array}$ & $\begin{array}{l}142 \\
115\end{array}$ & $\begin{array}{l}875 \\
819\end{array}$ & $\begin{array}{l}504 \\
418\end{array}$ & $\begin{array}{r}1,540 \\
791\end{array}$ & $\begin{array}{l}1.12 \\
1.25\end{array}$ \\
\hline
\end{tabular}

* Dog 131 : weight $13.2 \mathrm{~kg}$; sustaining infusion, $0.14 \mathrm{M} \mathrm{NaCl}$ at $8.5 \mathrm{ml} / \mathrm{min}$ beginning at $\mathrm{O}$ time. Control plasma, $\mathrm{Na} 140, \mathrm{~K} 2.6$. $\mathrm{Cl} 112$ $\mathrm{mEq} / \mathrm{L}$ with no significant change throughout.

$\dagger$ Carbonic anhydrase inhibiting activity, expressed in terms of micrograms of acetazolamide. 
TABLE II

Effect of $500 \mathrm{mg} / \mathrm{kg}$ of acetazolamide

\begin{tabular}{|c|c|c|c|c|c|c|c|c|c|c|c|c|c|c|c|c|c|c|}
\hline \multirow{2}{*}{$\begin{array}{l}\text { Total } \\
\text { elapsed } \\
\text { time }\end{array}$} & \multicolumn{6}{|c|}{ Plasma } & \multirow[b]{2}{*}{ GFR } & \multicolumn{5}{|c|}{ Urine } & \multicolumn{5}{|c|}{ Excreted/filtered } & \multirow{2}{*}{$\begin{array}{c}\mathrm{HCO}_{2} \\
\text { reab- } \\
\text { sorbed }\end{array}$} \\
\hline & $\mathrm{pH}$ & $\mathrm{PCO}_{2}$ & $\mathrm{HCO}_{3}$ & $\mathrm{Na}$ & $\mathrm{K}$ & $\mathrm{Cl}$ & & Flow & $\mathrm{Na}$ & $\mathrm{K}$ & $\mathrm{Cl}$ & $\mathrm{HCO}_{3}$ & $\mathrm{H}_{2} \mathrm{O}$ & $\mathrm{Na}$ & $\mathbf{K}$ & $\mathrm{Cl}$ & $\mathrm{HCO}_{2}$ & \\
\hline $\min$ & & $\begin{array}{c}m m \\
H g\end{array}$ & & $m E q$ & & & $\mathrm{ml} / \mathrm{min}$ & $\begin{array}{l}m l / \\
m i n\end{array}$ & & $\mu E q$ & $\operatorname{nin}$ & & & & $\%$ & & & $\begin{array}{c}m E q / 100 \\
m l G F R\end{array}$ \\
\hline \multicolumn{19}{|c|}{ A. Dog Hazel: weight $22 \mathrm{~kg}$. Sustaining infusion, $\mathrm{NaCl} 0.125 \mathrm{M}, \mathrm{NaHCO}_{3} 0.025 \mathrm{M}$, at $9.6 \mathrm{ml} / \mathrm{min}$ at $0 \mathrm{time}$} \\
\hline $\begin{array}{l}120-130 \\
130-140 \\
140-150 \\
150-158 \\
161-167 \\
167-173\end{array}$ & $\begin{array}{c}7.43 \\
\\
7.41 \\
\text { Acetazola } \\
7.60 \\
7.39\end{array}$ & $\begin{array}{c}37 \\
38 \\
\text { amide, } \\
30 \\
43\end{array}$ & $\begin{array}{l}23.6 \\
\\
23.4 \\
500 \mathrm{mg} \\
28.1 \\
25.5\end{array}$ & $\begin{array}{l}157 \\
\text { g/kg i.v } \\
159 \\
159\end{array}$ & $\begin{array}{l}2.6 \\
2.4 \\
2.4\end{array}$ & $\begin{array}{l}118 \\
119 \\
119\end{array}$ & $\begin{array}{l}81 \\
80 \\
83 \\
\\
66 \\
71\end{array}$ & $\begin{array}{r}8.0 \\
8.0 \\
8.4 \\
26.2 \\
22.3\end{array}$ & $\begin{array}{l}1,140 \\
1,140 \\
1,190 \\
3,790 \\
3,250\end{array}$ & $\begin{array}{r}67 \\
63 \\
71 \\
\\
178 \\
175\end{array}$ & $\begin{array}{r}800 \\
800 \\
848 \\
\\
1,886 \\
1,606\end{array}$ & $\begin{array}{r}292 \\
280 \\
286 \\
\\
1,520 \\
1,330\end{array}$ & $\begin{array}{r}9.9 \\
10.1 \\
10.1 \\
40.0 \\
31.6\end{array}$ & $\begin{array}{r}9.6 \\
\\
38.2 \\
30.4\end{array}$ & $\begin{array}{r}32.9 \\
113.4 \\
103.0\end{array}$ & $\begin{array}{c}8.7 \\
\\
24.2 \\
19.1\end{array}$ & $\begin{array}{l}15.2 \\
14.9 \\
15.0 \\
\\
82.6 \\
70.0\end{array}$ & $\begin{array}{l}2.00 \\
2.01 \\
1.99 \\
\\
0.49 \\
0.81\end{array}$ \\
\hline \multicolumn{19}{|c|}{ B. Dog 138: weight $12.7 \mathrm{~kg}$. Sustaining infusion, $\mathrm{NaCl} 0.11 \mathrm{M}, \mathrm{NaHCO}_{3} 0.035 \mathrm{M}$ at $9.6 \mathrm{ml} / \mathrm{min}$ at $0 \mathrm{time}$} \\
\hline $\begin{array}{l}120-130 \\
130-140 \\
140-150 \\
150-152 \\
153 \\
155-161 \\
161-167 \\
167-173\end{array}$ & $\begin{array}{c}7.30 \\
7.29 \\
7.30 \\
\text { Acetazola } \\
7.68 \\
7.49 \\
7.45 \\
7.38\end{array}$ & $\begin{array}{c}52 \\
54 \\
51 \\
\text { amide, } \\
29 \\
43 \\
43 \\
46\end{array}$ & $\begin{array}{l}26.1 \\
26.1 \\
26.1 \\
500 \mathrm{mg} \\
34.9 \\
33.3 \\
30.2 \\
29.1\end{array}$ & $\begin{array}{c}156 \\
156 \\
\mathrm{~g} / \mathrm{kg} \text { i.v } \\
164 \\
161\end{array}$ & $\begin{array}{l}1.6 \\
2.5 \\
2.5 \\
2.6\end{array}$ & $\begin{array}{l}119 \\
121 \\
124\end{array}$ & $\begin{array}{l}45 \\
38 \\
43\end{array}$ & $\begin{array}{r}23.8 \\
12.2 \\
8.5\end{array}$ & $\begin{array}{l}3,550 \\
1,930 \\
1,420\end{array}$ & $\begin{array}{r}121 \\
89 \\
86\end{array}$ & $\begin{array}{r}1,990 \\
922 \\
588\end{array}$ & $\begin{array}{r}1,180 \\
719 \\
607\end{array}$ & $\begin{array}{l}15.1 \\
17.1 \\
15.6\end{array}$ & $\begin{array}{l}13.6 \\
16.1 \\
14.4\end{array}$ & $\begin{array}{l}127.4 \\
127.1 \\
100.2\end{array}$ & $\begin{array}{r}9.6 \\
10.8 \\
9.5\end{array}$ & $\begin{array}{l}31.6 \\
36.6 \\
34.6\end{array}$ & $\begin{array}{l}1.79 \\
1.66 \\
1.71\end{array}$ \\
\hline
\end{tabular}

increase in chloride excretion and, although potassium excretion increased, most of the increment in bicarbonate was associated with a nearly equivalent rise in sodium excretion. Significant levels of carbonic anhydrase inhibiting activity were demonstrable in both plasma and urine. Urine flow increased slightly despite a drop in glomerular filtration rate.

Injection of $10.6 \mathrm{mg}$ per $\mathrm{kg}$ of CL 8490 on five other occasions was similarly without effect on water and electrolyte excretion. Acetazolanide in this dose never failed to produce a significant reduction in bicarbonate reabsorption, but in no case increased chloride excretion.

II. The effects of $500 \mathrm{mg} \mathrm{per} \mathrm{kg}$ of acctazolamide. In 15 experiments acetazolamide was administered intravenously at a dose of $500 \mathrm{mg}$ per $\mathrm{kg}$. On five occasions the drug was injected 2 to 3 hours after a comparable dose of analog, and in the remaining 10 experiments acetazolamide alone was injected. In Table II are summarized the results of two such experiments. In the first experiment (A), the dog had not received any other agent prior to injection of acetazolamide; in the other (B), a large dose of CL 8490 had been given approximately 90 minutes before, but its effect had almost entirely disappeared prior to injection of acetazolamide.

In both instances, injection of $500 \mathrm{mg}$ per $\mathrm{kg}$ of acetazolamide resulted in a significant rise in blood $\mathrm{pH}$ and plasma bicarbonate concentration. There was also a very large diuresis of water and electrolytes. At the height of the diuresis in Experi- ment A, approximately 40 per cent of the water, 38 per cent of the sodium and 83 per cent of the bicarbonate in the filtrate was diverted into the urine. In Experiment B, the effect was even greater, with excretion of about 60 per cent of the filtered water and sodium and 90 per cent of the bicarbonate. In both experiments the diuresis was quite evanescent, for it was clearly waning after the first 6-minute clearance period. In both experiments there was also a large chloride and potassium diuresis, net secretion of the latter becoming demonstrable. The reabsorption of bicarbonate was briefly reduced to $0.49 \mathrm{mEq}$ per $100 \mathrm{ml}$ glomerular filtrate in $\mathrm{A}$, and to $0.22 \mathrm{mEq}$ per $100 \mathrm{ml}$ glomerular filtrate in B. There was a slight reduction in glomerular filtration rate in both experiments.

In all the other experiments in which similar doses of acetazolamide were used the response was similar. The maximal rate of excretion of bicarbonate ranged from 70 to 95 per cent of the filtered load and the reduction in the rate of reabsorption ranged from approximately 45 per cent to 85 per cent of the control value, with an average of 65 per cent.

The maximal excretion of sodium and water was 20 to 57 per cent, and of chloride 13 to 45 per cent of the filtered load. As in the experiments in Table II, the glomerular filtration rate usually dropped slightly after the injection, but in a few cases there was no change. Qualitative tests of the urine for sugar in three experiments were negative. Phosphorus excretion, measured in sev- 
TABLE III

Effects of 2 mmoles/ $\mathrm{kg}$ of $\mathrm{NaOH}$ and $\mathrm{NaHCO}_{3}$

\begin{tabular}{|c|c|c|c|c|c|c|c|c|c|c|c|c|c|c|c|c|c|c|}
\hline \multirow{2}{*}{$\begin{array}{l}\text { Total } \\
\text { elapsed } \\
\text { time }\end{array}$} & \multicolumn{6}{|c|}{ Plasma } & \multirow[b]{2}{*}{ GFR } & \multicolumn{5}{|c|}{ Urine } & \multicolumn{5}{|c|}{ Excreted/filtered } & \multirow{2}{*}{$\begin{array}{c}\mathrm{HCO}_{3} \\
\text { reab- } \\
\text { sorbed }\end{array}$} \\
\hline & $\mathrm{pH}$ & $\mathrm{PCO}_{2}$ & $\mathrm{HCO}_{3}$ & $\mathrm{Na}$ & $\mathbf{K}$ & $\mathrm{Cl}$ & & Flow & $\mathrm{Na}$ & $\mathbf{K}$ & $\mathrm{Cl}$ & $\mathrm{HCO}_{3}$ & $\mathrm{H}_{2} \mathrm{O}$ & $\mathrm{Na}$ & $\mathrm{K}$ & $\mathrm{Cl}$ & $\mathrm{HCO}_{3}$ & \\
\hline $\min$ & & $\stackrel{m m}{H g}$ & & \multicolumn{3}{|c|}{$m E q / L$} & min & $\begin{array}{l}m i / \\
m i n\end{array}$ & & \multicolumn{3}{|c|}{$\mu E q / \min$} & \multicolumn{5}{|c|}{$\%$} & $\begin{array}{c}m E q / 100 \\
m l G F R\end{array}$ \\
\hline \multicolumn{19}{|c|}{ A. Dog $177,12.9 \mathrm{~kg}$. } \\
\hline $\begin{array}{l}144-154 \\
154-164 \\
165-167 \\
168-\end{array}$ & $\begin{array}{c}7.35 \\
7.41 \\
\mathrm{NaOH}, 20 \\
7.54\end{array}$ & $\begin{array}{c}51 \\
49 \\
6 \mathrm{mmo} \\
42\end{array}$ & $\begin{array}{c}32.5 \\
31.2 \\
\text { oles in } 90\end{array}$ & $\begin{array}{l}153 \\
153 \\
\mathrm{ml} \mathrm{H}\end{array}$ & $\begin{array}{l}2.7 \\
2.9 \\
{ }_{2} \mathrm{O} \text { i.v. }\end{array}$ & $\begin{array}{l}105 \\
103\end{array}$ & $\begin{array}{l}52 \\
48\end{array}$ & $\begin{array}{l}4.8 \\
3.8\end{array}$ & $\begin{array}{r}1,120 \\
903\end{array}$ & $\begin{array}{l}42 \\
41\end{array}$ & $\begin{array}{r}636 \\
546\end{array}$ & $\begin{array}{l}349 \\
310\end{array}$ & $\begin{array}{l}9.2 \\
7.9\end{array}$ & $\begin{array}{l}14.2 \\
12.3\end{array}$ & $\begin{array}{l}30.0 \\
29.5\end{array}$ & $\begin{array}{l}11.6 \\
11.1\end{array}$ & $\begin{array}{l}20.7 \\
20.7\end{array}$ & $\begin{array}{l}2.58 \\
2.48\end{array}$ \\
\hline $\begin{array}{l}170-176 \\
176-182 \\
182-188\end{array}$ & $\begin{array}{l}7.34 \\
7.42 \\
7.41 \\
7.37\end{array}$ & $\begin{array}{l}42 \\
52 \\
53 \\
56\end{array}$ & $\begin{array}{l}35.2 \\
34.8 \\
33.3\end{array}$ & $\begin{array}{l}153 \\
152 \\
153\end{array}$ & $\begin{array}{l}2.7 \\
2.8 \\
2.9\end{array}$ & $\begin{array}{l}100 \\
100 \\
102\end{array}$ & $\begin{array}{l}52 \\
37 \\
45\end{array}$ & $\begin{array}{l}7.0 \\
3.6 \\
2.8\end{array}$ & $\begin{array}{r}1,470 \\
784 \\
668\end{array}$ & $\begin{array}{l}68 \\
38 \\
48\end{array}$ & $\begin{array}{l}825 \\
417 \\
277\end{array}$ & $\begin{array}{l}571 \\
323 \\
327\end{array}$ & $\begin{array}{r}13.4 \\
9.7 \\
6.2\end{array}$ & $\begin{array}{r}18.5 \\
14.0 \\
9.7\end{array}$ & $\begin{array}{l}48.6 \\
36.5 \\
36.6\end{array}$ & $\begin{array}{r}15.9 \\
11.3 \\
6.0\end{array}$ & $\begin{array}{l}31.2 \\
25.1 \\
21.8\end{array}$ & $\begin{array}{l}2.42 \\
2.61 \\
2.60\end{array}$ \\
\hline \multicolumn{19}{|c|}{ B. Dog 50, $11.4 \mathrm{~kg}$. Sustaining infusion, $0.114 \mathrm{M} \mathrm{NaCl}$} \\
\hline $\begin{array}{r}0-10 \\
10-20 \\
21-25\end{array}$ & $\begin{array}{c}7.44 \\
7.44 \\
\mathrm{NaHCO}_{3},\end{array}$ & $\begin{array}{l}35 \\
33 \\
23 \mathrm{mr}\end{array}$ & $\begin{array}{l}24.0 \\
23.0 \\
\text { imoles in }\end{array}$ & $\begin{array}{l}148 \\
145 \\
75 \mathrm{ml}\end{array}$ & $\begin{array}{c}2.4 \\
2.4 \\
\mathrm{H}_{2} \mathrm{O} \text { i }\end{array}$ & $\begin{array}{l}114 \\
116 \\
. v .\end{array}$ & $\begin{array}{l}53 \\
57\end{array}$ & $\begin{array}{l}7.1 \\
6.9\end{array}$ & $\begin{array}{l}1,100 \\
1,110\end{array}$ & $\begin{array}{l}\mathbf{5 0} \\
\mathbf{5 0}\end{array}$ & $\begin{array}{l}895 \\
918\end{array}$ & $\begin{array}{l}226 \\
233\end{array}$ & $\begin{array}{l}13.4 \\
12.1\end{array}$ & $\begin{array}{l}14.0 \\
13.4\end{array}$ & $\begin{array}{l}39.3 \\
36.5\end{array}$ & $\begin{array}{l}14.8 \\
13.9\end{array}$ & $\begin{array}{l}17.8 \\
17.8\end{array}$ & $\begin{array}{l}1.97 \\
1.89\end{array}$ \\
\hline $\begin{array}{l}26-32 \\
32-38 \\
83-93 \\
93-103\end{array}$ & $\begin{array}{l}7.51 \\
7.50 \\
7.46 \\
7.48\end{array}$ & $\begin{array}{l}41 \\
37 \\
36 \\
34\end{array}$ & $\begin{array}{l}33.2 \\
29.1 \\
25.9 \\
25.4\end{array}$ & $\begin{array}{l}151 \\
147 \\
146 \\
145\end{array}$ & $\begin{array}{l}2.1 \\
2.1 \\
2.1 \\
2.1\end{array}$ & $\begin{array}{l}114 \\
114 \\
115 \\
115\end{array}$ & $\begin{array}{l}51 \\
60 \\
55 \\
57\end{array}$ & $\begin{array}{r}13.3 \\
13.5 \\
7.9 \\
7.7\end{array}$ & $\begin{array}{l}2,110 \\
2,030 \\
1,220 \\
1,170\end{array}$ & $\begin{array}{l}\mathbf{7 0} \\
\mathbf{6 0} \\
\mathbf{5 0} \\
\mathbf{5 0}\end{array}$ & $\begin{array}{r}1,440 \\
1,470 \\
885 \\
862\end{array}$ & $\begin{array}{l}722 \\
629 \\
347 \\
318\end{array}$ & $\begin{array}{l}26.1 \\
22.5 \\
14.4 \\
13.5\end{array}$ & $\begin{array}{l}27.4 \\
23.0 \\
15.2 \\
14.2\end{array}$ & $\begin{array}{l}65.4 \\
47.6 \\
43.3 \\
41.8\end{array}$ & $\begin{array}{l}24.8 \\
21.5 \\
14.0 \\
13.2\end{array}$ & $\begin{array}{l}42.6 \\
36.0 \\
24.4 \\
22.0\end{array}$ & $\begin{array}{l}1.90 \\
1.86 \\
1.96 \\
1.98\end{array}$ \\
\hline
\end{tabular}

eral experiments, did not change. Urine and plasma osmolality were measured (by depression of freezing point) in five experiments. Values were in the range of 320 to $380 \mathrm{mOsm}$ and were essentially equal in plasma and urine. Roughly estimated, either indirectly from the difference between total osmolality of the urine and the sum of the measured electrolytes or directly from the measurements of carbonic anhydrase inhibiting activity in the urine at the height of the diuresis (cf. Tables V and VI), the excretion of acetazolamide appeared to be less than 10 per cent of the total solute.

III. Sodium bicarbonate and sodium hydroxide. In order to determine whether any of the effects of acetazolamide could be attributed to the alkalinity of the infusate, experiments were carried out uncler comparable conditions, in which 2 mmoles per $\mathrm{kg}$ of $\mathrm{NaOH}$ or $\mathrm{NaHCO}_{3}$ was givenan amount estimated to be at least equal to the alkali given up to the body fluids by the quantities of alkaline acetazolamide (or CL 8490) injected in the previous experiments. ${ }^{2}$ Three experiments were carried out with sodium bicarbonate and

2 This quantity was calculated in the following manner. Acetazolamide has a $\mathrm{pKa}^{\prime}{ }_{1}$ of 7.4 and a $\mathrm{pKa}^{\prime}{ }_{2}$ of 9.1 ; the drug was injected at a $\mathrm{pH}$ of between 8.5 and 9.0 and was titrated by the blood to a $\mathrm{pH}$ of approximately 7.4 to 7.6. Therefore, it can be estimated that each buffer group would be titrated by approximately 0.5 equivalent per mole, or a total of $1 \mathrm{mEq}$ per mmole of drug administered. Since the total dose of drug was approximately 2 mmoles per $\mathrm{kg}$, the same load of $\mathrm{NaOH}$ or $\mathrm{NaHCO}_{3}$ was administered. Similar considerations apply to $C L 8490$ which has virtually the same $\mathrm{pK}^{\prime}$ values. four with sodium hydroxide. A summary of one of each type of experiment is shown in Table III. It can be seen that, although the injection of sodium hydroxide or sodium bicarbonate produced a rise in plasma bicarbonate concentration comparable with that effected by acetazolamide, there was a much smaller rise in the urinary excretion of sodium, chloride and water and very little increase in potassium excretion. Bicarbonate reabsorption was essentially unaffected although, as would be expected, the absolute excretion and the per cent of the filtered load excreted rose moderately.

IV. Effects of large doses of analog (CL 8490). In six experiments, $536 \mathrm{mg}$ per $\mathrm{kg}$ of $\mathrm{CL} 8490$ (equimolar with $500 \mathrm{mg}$ per $\mathrm{kg}$ of acetazolamide) was administered intravenously. Table IV presents the results of an experiment in which 536 $\mathrm{mg}$ per $\mathrm{kg}$ of CL 8490 was injected approximately 90 minutes after injection of $10.6 \mathrm{mg}$ per $\mathrm{kg}$. It is evident that the low dose produced only a very slight effect on electrolyte excretion and no effect on the reabsorption of bicarbonate, as already shown in the experiment of Table $I$. With the large dose of analog, approximately 40 per cent of the filtered water, sodium and chloride appeared in the urine in association with two-thirds of the filtered bicarbonate. Bicarbonate reabsorption was transiently reduced by 50 per cent to a minimum rate of $0.9 \mathrm{mEq}$ per $100 \mathrm{ml}$ glomerular filtrate.

Tables V and VI summarize two experiments in which a large dose of CL 8490 was compared 
with an equimolar dose of acetazolamide. In the experiment of Table $\mathrm{V}$, the injection of analog increased the rate of sodium excretion from 6 to 28 per cent of the filtered load and chloride excretion from 2 to 21 per cent of the filtered load. Urine flow rose from 6.1 to $19.7 \mathrm{ml}$ per minute, and at the height of the diuresis 34 per cent of the volume of the filtrate was excreted. Bicarbonate excretion was 47 per cent of the filtered load, while the reabsorptive rate dropped 25 per cent. Subsequently, injection of acetazolamide resulted in a similar effect, with an increase in sodium excretion from 9 to 32 per cent of the load, in water from 8 to 33 per cent, and in chloride from 3 to 18 per cent. Bicarbonate excretion increased to a rate equal to 61 per cent of the filtered load and reabsorption was reduced by 37 per cent. Plasma and urine contained large quantities of carbonic anhydrase inhibiting activity following injection of acetazolamide, but never showed more than traces of activity after the analog.

The experiment in Table VI illustrates the more usual result, in that there was a distinctly greater effect on electrolyte excretion with acetazolamide than with CL 8490 . With CL 8490 urine flow increased by $5 \mathrm{ml}$ per minute, sodium excretion increased from 14 to 26 per cent of the filtered load, water from 13 to 28 per cent, chloride from 11 to 18 per cent, and bicarbonate from 30 to 55 per cent. Bicarbonate reabsorption was reduced by approximately 20 per cent. By contrast, after acetazolamide urine flow increased by $13 \mathrm{ml}$ per minute and the maximal excretion of sodium rose from 13 to 40 per cent of the load, of bicarbonate from 34 to 75 per cent of the load, and of chloride from 8 to 27 per cent of the load. Bicarbonate reabsorption was reduced by approximately 55 per cent. As in the previous experiment, carbonic anhydrase inhibiting activity in urine was negligible immediately after administration of CL 8490, but very high after acetazolamide.

In Figure 1 is shown the maximal excretion of sodium following each of the experiments with acetazolamide and CL 8490 . Sodium excretion, plotted as a per cent of the filtered load, is related to the simultaneous urine to plasma ratio for inulin or creatinine. Solid circles represent data obtained with acetazolamide and open circles, CL 8490. It is seen that maximal sodium excretion ranged from approximately 20 to 55 per cent of the filtered load with acetazolamide and from 20 to 40 per cent of the load with CL 8490 . Although there was overlap, acetazolamide appeared to have a substantially greater effect. The heavy solid line in the figure represents the theoretical relationship between sodium and water excretion which would obtain if sodium were excreted isotonically. The close fit of the experimental points to this line indicates the virtually isotonic nature of the urine during diuresis. For comparison, the dotted lines in the lower part of the figure show the approximate range of the relationship between sodium and water observed during maximal osmotic diuresis with mannitol (8) and with urea (9). It is apparent that sodium excretion at any given rate of water excretion was considerably less with osmotic diuresis than with the drugs studied here. To the authors' knowledge, the maximal rates of sodium excretion observed in the

TABLE IV

Comparative effects of $10.6 \mathrm{mg} / \mathrm{kg}$ and $536 \mathrm{mg} / \mathrm{kg}$ of $\mathrm{CL} 8490^{*}$

\begin{tabular}{|c|c|c|c|c|c|c|c|c|c|c|c|c|c|c|c|c|c|c|}
\hline \multirow{2}{*}{$\begin{array}{l}\text { Total } \\
\text { elapsed } \\
\text { time }\end{array}$} & \multicolumn{6}{|c|}{ Plasma } & \multirow[b]{2}{*}{ GFR } & \multicolumn{5}{|c|}{ Urine } & \multicolumn{5}{|c|}{ Excreted/filtered } & \multirow{2}{*}{$\begin{array}{l}\mathrm{HCO}_{3} \\
\text { reab- } \\
\text { sorbed }\end{array}$} \\
\hline & $\mathrm{pH}$ & $\mathrm{PCO}_{2}$ & $\mathrm{HCO}_{3}$ & $\mathrm{Na}$ & $\mathbf{K}$ & $\mathrm{Cl}$ & & Flow & $\mathrm{Na}$ & $\mathbf{K}$ & $\mathrm{Cl}$ & $\mathrm{HCO}_{3}$ & $\mathrm{H}_{2} \mathrm{O}$ & $\mathrm{Na}$ & $\mathbf{K}$ & $\mathrm{Cl}$ & $\mathrm{HCO}_{3}$ & \\
\hline $\min$ & & $\underset{H g}{m m}$ & \multicolumn{4}{|c|}{$m E q / L$} & $\mathrm{ml} / \mathrm{min}$ & min & \multicolumn{4}{|c|}{$\mu E q / \min$} & & & $\%$ & & & $\begin{array}{c}m E q / 100 \\
m l G F R\end{array}$ \\
\hline $\begin{array}{l}50-60 \\
60-70 \\
70-80 \\
80-81\end{array}$ & $\begin{array}{c}7.42 \\
7.38 \\
7.38 \\
\text { CL } 8490,\end{array}$ & $\begin{array}{c}29 \\
32 \\
32 \\
10.6\end{array}$ & $\begin{array}{c}19.0 \\
19.4 \\
19.6 \\
\mathrm{mg} / \mathrm{kg} \mathrm{i}\end{array}$ & $\begin{array}{l}149 \\
149 \\
148 \\
\text { i.v. }\end{array}$ & $\begin{array}{l}3.3 \\
3.4 \\
3.5\end{array}$ & $\begin{array}{l}121 \\
123 \\
122\end{array}$ & $\begin{array}{l}65 \\
63 \\
64\end{array}$ & $\begin{array}{l}5.9 \\
5.0 \\
6.1\end{array}$ & $\begin{array}{l}1,070 \\
1,110 \\
1,120\end{array}$ & $\begin{array}{l}76 \\
81 \\
89\end{array}$ & $\begin{array}{l}1,110 \\
1,140 \\
1,180\end{array}$ & $\begin{array}{l}60 \\
63 \\
66\end{array}$ & $\begin{array}{l}9.1 \\
9.4 \\
9.5\end{array}$ & $\begin{array}{l}11.0 \\
11.8 \\
11.8\end{array}$ & $\begin{array}{l}35.4 \\
37.8 \\
39.7\end{array}$ & $\begin{array}{l}14.1 \\
14.7 \\
15.1\end{array}$ & $\begin{array}{l}4.9 \\
5.2 \\
5.3\end{array}$ & $\begin{array}{l}1.81 \\
1.84 \\
1.86\end{array}$ \\
\hline $\begin{array}{l}85-91 \\
91-97 \\
97-153\end{array}$ & $\begin{array}{c}7.41 \\
7.40 \\
\text { Discard }\end{array}$ & $\begin{array}{l}31 \\
30\end{array}$ & $\begin{array}{l}19.7 \\
19.1\end{array}$ & $\begin{array}{l}149 \\
147\end{array}$ & $\begin{array}{l}3.3 \\
3.4\end{array}$ & $\begin{array}{l}123 \\
121\end{array}$ & $\begin{array}{l}66 \\
60\end{array}$ & $\begin{array}{l}7.2 \\
6.3\end{array}$ & $\begin{array}{l}1,270 \\
1,160\end{array}$ & $\begin{array}{l}108 \\
105\end{array}$ & $\begin{array}{l}1,270 \\
1,160\end{array}$ & $\begin{array}{l}91 \\
87\end{array}$ & $\begin{array}{l}10.9 \\
10.5\end{array}$ & $\begin{array}{l}12.9 \\
13.2\end{array}$ & $\begin{array}{l}49.6 \\
51.5\end{array}$ & $\begin{array}{l}15.6 \\
16.0\end{array}$ & $\begin{array}{l}7.0 \\
7.6\end{array}$ & $\begin{array}{l}1.83 \\
1.77\end{array}$ \\
\hline $\begin{array}{l}153-163 \\
163-173 \\
173-175 \\
175\end{array}$ & $\begin{array}{c}7.41 \\
7.41 \\
\text { CL } 8490 \\
8.00\end{array}$ & $\begin{array}{c}29 \\
29 \\
536 \mathrm{n} \\
11\end{array}$ & $\begin{array}{c}18.7 \\
21.0 \\
\mathrm{mg} / \mathrm{kg} \\
28.5\end{array}$ & $\begin{array}{l}144 \\
144 \\
. v .\end{array}$ & $\begin{array}{l}3.2 \\
3.3\end{array}$ & $\begin{array}{l}119 \\
120\end{array}$ & $\begin{array}{l}62 \\
68\end{array}$ & $\begin{array}{l}6.5 \\
6.2\end{array}$ & $\begin{array}{l}1,160 \\
1,140\end{array}$ & $\begin{array}{l}87 \\
88\end{array}$ & $\begin{array}{l}1,160 \\
1,170\end{array}$ & $\begin{array}{l}80 \\
70\end{array}$ & $\begin{array}{r}10.5 \\
9.1\end{array}$ & $\begin{array}{l}13.0 \\
11.6\end{array}$ & $\begin{array}{l}43.9 \\
39.2\end{array}$ & $\begin{array}{l}15.7 \\
14.3\end{array}$ & $\begin{array}{l}6.9 \\
4.9\end{array}$ & $\begin{array}{l}1.74 \\
2.00\end{array}$ \\
\hline $\begin{array}{l}178-184 \\
184-190\end{array}$ & $\begin{array}{l}7.63 \\
7.49\end{array}$ & $\begin{array}{l}27 \\
29\end{array}$ & $\begin{array}{l}28.2 \\
22.3\end{array}$ & $\begin{array}{l}153 \\
154\end{array}$ & $\begin{array}{l}3.5 \\
3.0\end{array}$ & $\begin{array}{l}110 \\
118\end{array}$ & $\begin{array}{l}52 \\
52\end{array}$ & $\begin{array}{l}20.8 \\
12.5\end{array}$ & $\begin{array}{l}3,270 \\
2,120\end{array}$ & $\begin{array}{l}203 \\
153\end{array}$ & $\begin{array}{l}2,460 \\
1,700\end{array}$ & $\begin{array}{l}998 \\
541\end{array}$ & $\begin{array}{l}40.0 \\
24.0\end{array}$ & $\begin{array}{l}41.1 \\
26.5\end{array}$ & $\begin{array}{r}111.5 \\
98.1\end{array}$ & $\begin{array}{l}\mathbf{4 3 . 0} \\
27.7\end{array}$ & $\begin{array}{l}68.1 \\
46.6\end{array}$ & $\begin{array}{l}0.90 \\
1.19\end{array}$ \\
\hline
\end{tabular}

* Dog 127 : weight $12.8 \mathrm{~kg}$; sustaining infusion, $0.15 \mathrm{M} \mathrm{NaCl}$ at $8.5 \mathrm{ml} / \mathrm{min}$ at 0 time. 

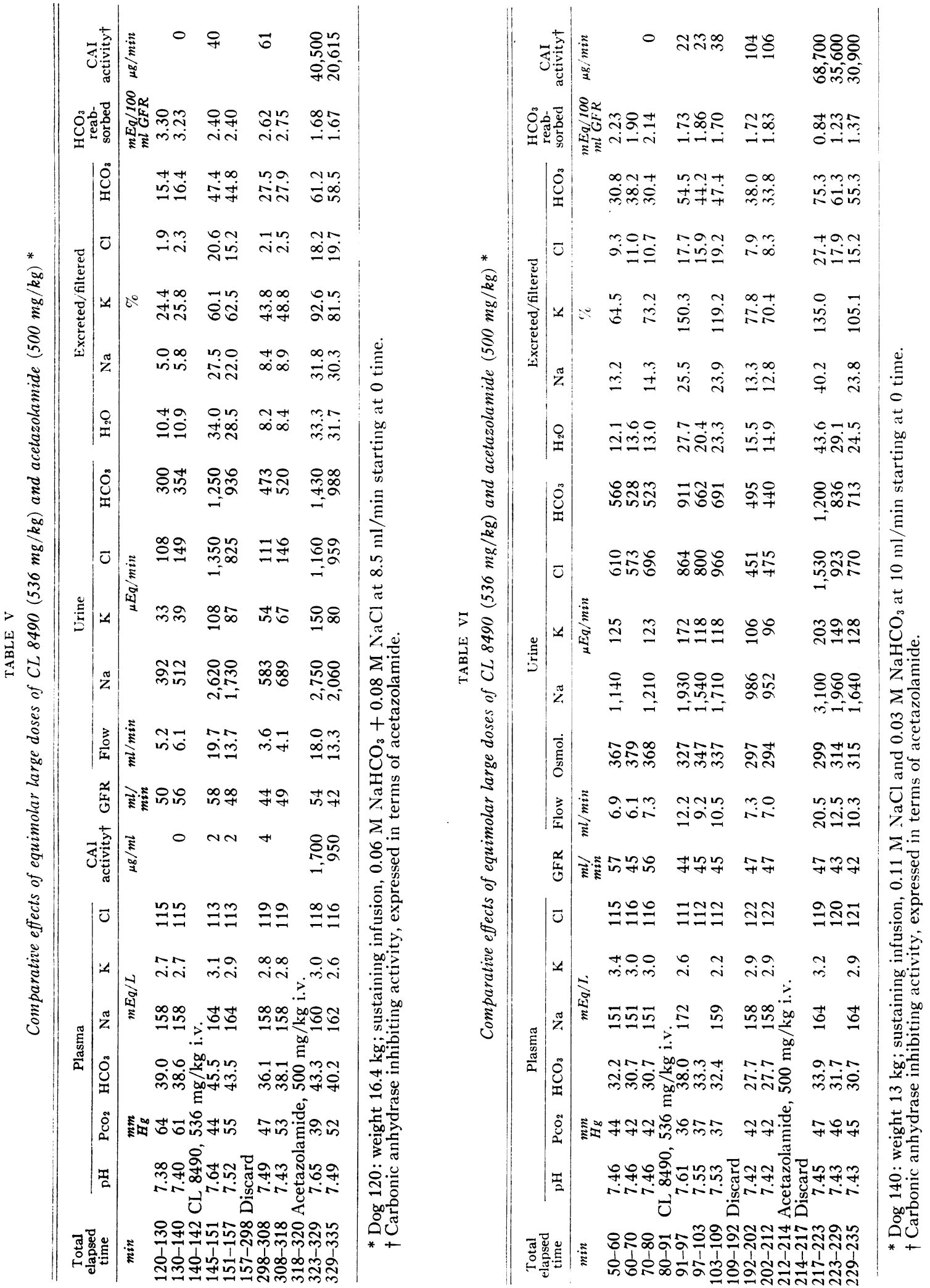


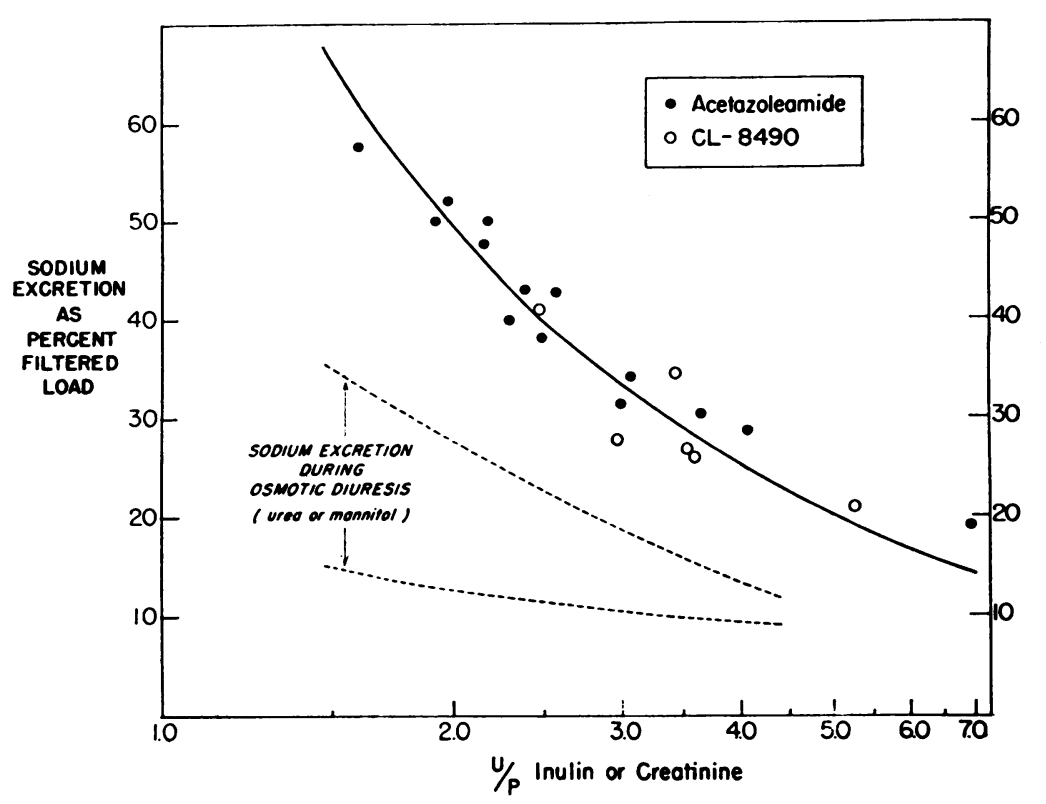

Fig. 1. Maximal sonium excretion following acetazolamide (500 MG PER KG) OR CL 8490 (536 MG PER KG). This is plotted as a per cent of the filtered load in relation to the simultaneous urine to plasma ratio for inulin or creatinine. Solid dots represent acetazolamide, open circles CL 8490. The heavy solid line represents the theoretical relationship between these parameters for the excretion of an isotonic solution of sodium. Note that the experimental points closely fit this theoretical line. For comparison, the dotted lines in the lower part of the figure indicate the range of the relationship between excretion of sodium and water during maximal osmotic diuresis with mannitol (8) and urea (9).

present study exceed any which have previously been reported.

\section{DISCUSSION}

These experiments show that rapid intravenous administration of $500 \mathrm{mg}$ per $\mathrm{kg}$ of acetazolamide produces a large, though transient, diuresis which considerably exceeds that which has been produced by any other experimental technique. At the height of this effect as much as 40 to 60 per cent of the sodium and water in the glomerular filtrate was diverted into the urine, together with 25 to 50 per cent of the filtered chloride. Bicarbonate reabsorption was depressed by 40 to 85 per cent from control rates and the rate of excretion was as much as 70 to 95 per cent of the filtered load. Aside from its magnitude, the feature of this diuresis which distinguished it from the effects of the usual small doses of acetazolamide was the massive chloruresis. When $10 \mathrm{mg}$ per $\mathrm{kg}$ was given, there was little or no effect on chloride, and almost all of the increment in anion was due to bicarbonate (Table I). By contrast, in the present experiments with $500 \mathrm{mg}$ per $\mathrm{kg}$, although there was a further enhancement of bicarbonate excretion, a large part of the increased excretion of anion was due to chloride.

The explanation for this phenomenon was at first thought to reside solely in the carbonic anhydrase inhibiting activity of the large dose (4). It would now appear that an additional mechanism must be invoked because equimolar large doses of an inactive analog (CL 8490) also produce a substantial diuresis of electrolyte and water. This diuresis is not usually as large as that resulting from acetazolamide, but closely resembles the latter in its duration and in its effect on urine composition.

It seems clear from the data at hand that neither the osmotic effect nor the acute systemic alkalinizing action of the large dose of the sodium salts of acetazolamide or CL 8490 can explain the results. 
An osmotic diuresis would appear to be excluded by the fact that the drug constituted only a small fraction of total urine solute, probably less than 10 per cent. That neither the sodium load nor the extracellular alkalinizing effect of the sulfonamide base could account for the depression of chloride and bicarbonate reabsorption was demonstrated by control experiments in which loads of sodium bicarbonate and sodium hydroxide equivalent to the alkali yielded by the sulfonamides were found not to reduce the reabsorption of bicarbonate and to only slightly increase the excretion of sodium and chloride. Administration of the alkali produced a moderate bicarbonate diuresis, but this was due to the rise in plasma bicarbonate level and not to any significant reduction in reabsorption.

What then is the explanation for the diuretic action of CL 8490 and for that part of the action of the large dose of acetazolamide which presumably is not related to carbonic anhydrase inhibition? The available data do not permit a definite answer to this question. However, in view of the large doses required to produce diuresis and the transient nature of the effect, it is tentatively suggested that the mechanism does not involve direct inhibition of an enzymatic process required for electrolyte transport. Rather, it would appear more likely that the effect depends upon some temporary change in renal cell composition resulting from the sudden accumulation of large amounts of drug. There is evidence that acetazolamide is both secreted and reabsorbed by tubular cells (10) and it is reasonable to assume similar handling of the analog. Movement of the monobasic form of either drug from the relatively alkaline plasma or proximal tubular fluid ( $\mathrm{pH} 7.5$ to 7.7 ) into the relatively acid renal cells (estimated $\mathrm{pH}<7.0$ ) would result in binding of intracellular protons by the weaker of the two basic groups on each molecule ( $\mathrm{pK}_{\mathrm{a}}^{\prime} 7.4$ and 7.7 , respectively) and as a consequence cell $\mathrm{pH}$ would rise. Since there is strong evidence to suggest that reabsorption of bicarbonate involves a sodium-hydrogen exchange (1), acute reduction in the availability of protons within the tubular cell might inhibit this process and produce a bicarbonate diuresis. Whether a similar sodium-hydrogen exchange is also involved in the reabsorption of chloride (3) is not known, but if such were the case, a rise in cellular $\mathrm{pH}$ would also be expected to reduce the reabsorption of chloride. If, on the other hand, a sodiumhydrogen exchange does not precede chloride reabsorption, it might be postulated that increased cell $\mathrm{pH}$ in some manner slows the metabolic processes upon which all active sodium transport depends. Since chloride reabsorption appears to be a passive result of active sodium transport (11), the final results would be the same. The transient nature of the diuretic effect, assuming the latter to be the result of abrupt changes in cell $\mathrm{pH}$, could be explained on the basis of the brief time during which plasma and tissue concentrations of drug might remain at levels high enough to affect celt $\mathrm{pH}$, and to rapid turnover of protons within the cell, which would be expected to restore the usual $\mathrm{pH}$ very quickly and thus nullify the diuretic effect.

While such speculation seems consistent with available data, it is obvious that alternative mechanisms cannot be excluded. Thus, for example, it is possible that the diuretic action shared by acetazolamide and CL 8490 resides in some other property of the thiadiazole-sulfonamide configuration which also belongs to the benzothiadiazole-sulfonamides of the chlorothiazide family. The latter are potent saluretics which in relatively low dosage produce changes in electrolyte excretion qualitatively similar to those reported here $(12,13)$. More information will be needed to settle this question.

Finally, it should be emphasized that, in three of five paired experiments, acetazolamide appeared to have a considerably greater effect on sodium and water than did CL 8490 . The maximal diuresis achieved with CL 8490 never approached that observed in other experiments with acetazolamide (Figure 1). It is likely, therefore, that an appreciable part of the action of the $500 \mathrm{mg}$ per $\mathrm{kg}$ dose of acetazolamide is in fact due to carbonic anhydrase inhibition. Limited supplies of CL 8490 unfortunately prevented a more definitive quantitative comparison of acetazolamide with CL 8490.

\section{SUMMARY AND CONCLUSIONS}

Intravenous injection of $500 \mathrm{mg}$ per $\mathrm{kg}$ of sodium acetazolamide in dogs produced a massive but transient diuresis in which as much as 40 to 60 per cent of the filtered sodium and water and 25 
to 50 per cent of the filtered chloride were diverted into the urine. Bicarbonate reabsorption was depressed by 40 to 85 per cent from control rates and the rate of excretion reached 70 to 95 per cent of the filtered load. A substantial part of this effect is probably not explained by inhibition of carbonic anhydrase, because the sodium salt of the $\mathrm{N}^{2}$ methyl analog of acetazolamide (CL 8490), which has virtually no carbonic anhydrase inhibiting activity in vivo or in vitro, was found to produce a similar though somewhat smaller diuresis.

The data indicate that the diuretic action shared by the sodium salts of acetazolamide and CL 8490 cannot be explained on the basis either of the osmotic activity of the administered drugs or their extracellular alkalinizing effects. In view of the size of the dose required and of the transiency of the effect, it is proposed that the shared mechanism of action depends upon some temporary alteration in renal cell composition. It is tentatively suggested that depression of electrolyte reabsorption may result from transient intracellular alkalosis produced by cellular accumulation of the monobasic form of the drug.

\section{REFERENCES}

1. Pitts, R. F. Renal excretion of acid. Fed. Proc. 1948, 7, 418.

2. Pitts, R. F., and Alexander, R. S. The nature of the renal tubular mechanism for acidifying the urine. Amer. J. Physiol. 1945, 144, 239.

3. Berliner, R. W. Renal secretion of potassium and hydrogen ions. Fed. Proc. 1952, 11, 695.
4. Schwartz, W. B., Danzig, L. E., and Relman, A. S. Role of carbonic anhydrase in renal tubular reabsorption of bicarbonate (abstract). Amer. J. Med. 1953, 14, 526.

5. Schwartz, W. B., Porter, R., and Relman, A. S. Electrolyte and water diuresis produced by inactive $\mathrm{N}^{5}$-substituted acetazoleamide analogs. Fed. Proc. 1956, 15, 166.

6. Maren, T. H. Carbonic anhydrase inhibition. V. $\mathrm{N}^{5}$-substituted 2-acetyl-amino-1,3,4-thiadiazole-5sulfonamides : Metabolic conversion and use as control substances. J. Pharmacol. exp. Ther. 1956, 117, 385.

7. Maren, T. H., Ash, V. I., and Bailey, E. M., Jr. Carbonic anhydrase inhibition. II. A method for determination of carbonic anhydrase inhibitors, particularly of Diamox. Bull. Johns Hopk. Hosp. 1954, 95, 244.

S. Wesson, L. G., Jr., and Anslow, W. P., Jr. Excretion of sodium and water during osmotic diuresis in the dog. Amer. J. Physiol. 1948, 153, 465.

9. Mudge, G. H., Foulks, J., and Gilman, A. Effect of urea diuresis on renal excretion of electrolytes. Amer. J. Physiol. 1949, 158, 218.

10. Weiner, I. M., Washington, J. A., II, and Mudge, G. H. Studies on the renal excretion of salicylate in the dog. Bull. Johns Hopk. Hosp. 1959, 105, 284.

11. Giebisch, G., and Windhager, E. E. Chloride fluxes across single proximal tubules of Necturus kidney. Fed. Proc. 1959, 18, 52.

12. Beyer, K. H. The mechanism of action of chlorothiazide. Ann. N. Y. Acad. Sci. 1958, 71, 363.

13. Pitts, R. F., Krück, F., Lozano, R., Taylor, D. W., Heidenreich, O.P.A., and Kessler, R. H. Studies on the mechanism of diuretic action of chlorothiazide. J. Pharmacol. exp. Ther. 1958, 123, 89. 